\title{
IMPLEMENTASI METODE LINEAR CONGRUENT METHOD PADA GAME EDUKASI PEMBELAJARAN HURUF HIJAIYAH BERBASIS ANDROID
}

\author{
Agung Kharisma Hidayah ${ }^{1}$, Cahyo Prihantoro ${ }^{2}$, Sandhy Fernandez ${ }^{3}$ \\ ${ }^{1,3}$ Teknik Informatika, Fakultas Teknik, Universitas Muhammadiyah Bengkulu \\ ${ }^{2}$ Sistem Informasi, Fakultas Teknik, Universitas Muhammadiyah Bengkulu \\ Jl. Bali Po. Box, 118 Kota Bengkulu 38119 \\ (Telp 0736-22765 Fak. 0736-26161) \\ ${ }^{1}$ kharisma@umb.ac.id \\ ${ }^{2}$ cahyo@umb.ac.id \\ ${ }^{3}$ sandhy.fernandez@gmail.com
}

Abstrak: Ilmu agama khususnya hijaiyah bagi anak sangat penting sebagai bekal untuk dasar hidup mereka dalam menghadapi kehidupan di masa mendatang. Agar game edukasi menjadi semakin menarik saat dimainkan, maka penulis menerapkan salah satu metode yang dapat membangkitkan bilangan acak semu yaitu Linear Congruent Method (LCM). LCM dapat diimplementasikan sebagai metode pengacakan soal yang terdapat dalam menu quis. Dari hasil pengujian menggunakan black-box, sistem dalam aplikasi tersebut bekerja sesuai dengan apa yang diharapkan. Sedangkan pada pengujian kuisioner aplikasi yang dibangun masuk ke kategori "Baik" dengan hasil rata-rata 76,40\%.

Kata kunci: hijaiyah, linear congruent method, android.

Abstract: The science of religion, especially hijaiyah for children, is very important as a provision for the basis of their life in facing life in the future. In order for educational game to be more interesting when played, the authors apply one method that can generate pseudo random numbers, namely the Linear Congruent Method (LCM). LCM can be implemented as a method of randomizing the questions contained in the quis menu. From the test result using the black-box, the system in the application is working as expected. While in the application questionnaise test that was built into the "good" category with an average result of $76,40 \%$.

Keywords: hijaiyah, linear congruent method, android.

\section{PENDAHULUAN}

Perkembangan teknologi yang semakin pesat saat ini telah membuat banyak perubahan dalam gaya hidup masyarakat. Salah satu perubahannya adalah banyaknya penggunaan media elektronik (mobile smartphone) berbentuk aplikasi[1] dalam kehidupan sehari-hari. Penggunaannya bisa berupa browsing, media sosial, bermain game, dan sebagainya. [2]

Pendidikan bertugas untuk menyiapkan peserta didik agar dapat mencapai peradaban yang maju melalui perwujudan suasana belajar yang kondusif, menarik, dan kreatif [3]. Pendidikan dasar yang menjadi landasan bagi pengembangan pendidikan pada jenjang selanjutnya, haruslah mampu berfungsi mengembangkan potensi diri dan juga sikap serta kemampuan dasar yang diperlukan untuk hidup dimasyarakat, terutama untuk menghadapi perubahan-perubahan dalam masyarakat. Manusia belajar terus-menerus untuk mampu mencapai kemandirian dan beradaptasi terhadap berbagai perubahan lingkungan [4]. 
Jurnal Pseudocode, Volume VIII Nomor 1, Februari 2021, ISSN 2355-5920, e-ISSN 2655-1845 www.ejournal.unib.ac.id/index.php/pseudocode

Salah satu pendidikan yang sangat penting adalah pendidikan agama yang diajarkan sejak dini. Ilmu agama khususnya hijaiyah bagi anak sangat penting sebagai bekal hidup mereka dalam menghadapi kehidupan dimasa mendatang. Belajar Al-Qur'an adalah suatu proses yang dimulai dari mengeja huruf-huruf hijaiyah hingga membaca AlQur'an secara keseluruhan dan itu semua membutuhkan waktu yang tidak sebentar. Pembelajaran huruf hijaiyah bagi anak memang tidak mudah. Sehingga diperlukan sebuah sarana pembelajaran yang bisa memaksimalkan daya tangkap anak untuk membantu anak belajar dengan cara melihat, mendengar, dan melakukan [5]. Hal ini perlu diperhatikan tidak hanya oleh guru atau pendidik tetapi orang tua juga sangat berperan penting untuk suatu pembelajaran dengan media elektronik (mobile smartphone). Salah satu media bermain eletronik yang memiliki content pendidikan lebih dikenal dengan istilah game edukasi.

Game edukasi (education games) merupakan sebuah permainan yang digunakan dalam proses pembelajaran dan dalam permainan tersebut mengandung unsur mendidik atau nilai-nilai pendidikan [6]. Massachussets Institude of Technologi (MIT) berhasil membuktikan bahwa game sangat berguna untuk meningkatkan logika dan pemahaman pemain terhadap suatu masalah melalui proyek game yang dinamai Scratch. Berdasarkan hasil penelitian sebelumnya, tidak diragukan lagi bahwa game edukasi dapat menunjang proses pendidikan. [7]

Game berjenis edukasi ini bertujuan untuk memancing minat belajar anak terhadap materi pembelajaran sambil bermain, sehingga pemain diharapkan bisa lebih mudah memahami materi pelajaran yang disajikan. Adapun metode yang diterapkan dalam game edukasi ini adalah Linear Congruent Method (LCM).

Linear Congruent Method (LCM) merupakan metode pembangkit bilangan acak yang banyak dipergunakan dalam program komputer. Bilangan acak yang dibangkitkan oleh komputer merupakan bilangan acak semu, karena pembangkitnya menggunakan operasi-operasi aritmatika [8]. Algoritme Linear Congruent Method (LCM) digunakan pada pengacakan soal yang ada didalam game edukasi dan terdapat dalam menu quis. Pemakaian metode LCM untuk pengacakan nomor soal terbukti efektif, karna dapat meminimalisir kemungkinan munculnya soal-soal yang sama.

Pada penelitian sebelumnya yang berjudul Pembuatan Game Pembelajaran Pengenalan Huruf Hijaiyah Di Taman Kanak-Kanak (TK) Az-Zalfa Sidoharjo Pacitan sudah pernah dibuat sebuah game edukasi pembelajaran huruf hijaiyah [9]. Namun materi yang disajikan hanya sekedar pengenalan huruf-huruf hijaiyah saja dan tidak menerapkan metode pengacakan pada soal-soal soal kuisnya. Hal tersebut dapat mengakibatkan mucul soal-soal yang sama secara berulang.

Berdasarkan latar belakang diatas, penulis tertarik untuk untuk mengembangkan game edukasi pembelajaran huruf hijaiyah yang bukan hanya mengenalkan huruf, namun juga mengenalkan dasar-dasar harokat. Kemudian juga menerapkan sebuah metode pengacakan pada soalsoal kuis yang disajikan dalam aplikasi tersebut.

\section{LANDASAN TEORI}

\section{A. Pengertian Game}

Menurut Ernest Adams dan Andrew Rollings dalam buku Fundamentals of game design, game merupakan salah satu jenis kegiatan bermain 
Jurnal Pseudocode, Volume VIII Nomor 1, Februari 2021, ISSN 2355-5920, e-ISSN 2655-1845 www.ejournal.unib.ac.id/index.php/pseudocode

dengan pemainnya berusaha meraih tujuan dari game tersebut dengan melakukan aksi sesuai aturan dari game tersebut [10].

Game merupakan sebuah sarana hiburan yang digemari oleh masyarakat [11]. Game digunakan untuk menyampaikan suatu pesan kepada orang umum dalam bentuk permainan yang dapat menghibur [12]. Selain digunakan untuk menghilangkan rasa penat dalam beraktivitas, game juga berfungsi untuk melatih pola pikir seseorang dalam mencari solusi untuk memecahkan suatu masalah yang ada dalam sebuah game [11].

\section{B. Pengertian Edukasi}

Dalam kamus besar bahasa Inggris education berarti pendidikan. Pendidikan berasal dari kata didik atau mendidik yang berarti memelihara dan membentuk latihan. Sedangkan dalam kamus besar Bahasa Indonesia (1991) pendidikan diartikan sebagai proses pengubah sikap dan tata laku seseorang atau sekelompok orang dalam usaha mendewasakan manusia melalui upaya pengajaran dan pelatihan.

Pendidikan adalah sebuah proses pembelajaran yang didapat oleh setiap manusia, dalam hal ini adalah peserta didik. Tujuannya adalah untuk membuat peserta didik itu paham, mengerti serta mampu berpikir lebih kritis. Pendidikan dapat dirumuskan sebagai tuntunan pertumbuhan manusia sejak lahir hingga tercapai kedewasaan jasmani dan rohani, dalam interaksi alam dan lingkungan masyarakatnya. Pendidikan merupakan proses yang terus menerus tidak berhenti. Pendidikan bisa didapat secara formal maupun non formal. Pendidikan formal diperoleh dari suatu pembelajaran yang terstruktur yang telah dirancang oleh suatu institusi [3].

\section{Game Edukasi}

Education game adalah game yang khusus dirancang untuk mengajarkan user suatu pembelajaran tertentu, pengembangan konsep dan pemahaman dan membimbing mereka dalam melatih kemampuan mereka, serta memotivasi mereka untuk memainkannya.

Perancangan education game yang baik haruslah memenuhi kriteria dari education game itu sendiri [13]. Berikut ini beberapa kriteria dari education game, yaitu :

1. Nilai keseluruhan (Overall Value)

Nilai keseluruhan dari suatu game terpusat pada desain dan panjang durasi game. Aplikasi ini dibangun dengan desain yang menarik dan interaktif. Untuk penentuan panjang durasi, aplikasi ini menggunakan fitur timer.

\section{Dapat digunakan (Usability)}

Mudah digunakan dan diakses adalah poin penting bagi membuat game. Aplikasi ini merancang system dengan interface yang user friendly sehingga user dengan mudah dapat mengakses aplikasi.

\section{Keakuratan (Accuracy)}

Keakuratan diartikan sebagai bagaimana kesuksesan model atau gambaran sebuah game dapat dituangkan ke dalam percobaan atau perancangannya. Perancangan aplikasi ini harus sesuai dengan model game pada tahap perencanaan.

\section{Kesesuaian (Appropriateness)}

Kesesuaian dapat diartikan bagaimana isi dan desain game dapat diadaptasikan terhadap keperluan user dengan baik. Aplikasi ini menyediakan menu dan fitur yang diperlukan user untuk membantu pemahaman user dalam menggunakan aplikasi. 
Jurnal Pseudocode, Volume VIII Nomor 1, Februari 2021, ISSN 2355-5920, e-ISSN 2655-1845 www.ejournal.unib.ac.id/index.php/pseudocode

D. Linear Congruent Method (LCM)

Algoritme Linear Congruent Method (LCM) merupakan proses menurunkan secara acak nilai variabel secara tidak pasti secara berulang-ulang untuk mensimulasikan model [14]. Metode LCM bertujuan untuk memunculkan variabel acak melalui sampling dari distribusi probabilitas. LCM didefinisikan dalam persamaan sebagai berikut :

$\mathrm{Xn}=(\mathrm{a} \mathrm{Xn}-1+\mathrm{b}) \bmod \mathrm{m}$

Dimana :

$\mathrm{n} \quad=$ bilangan asli

$\mathrm{Xn} \quad=$ bilangan acak ke-n

$\mathrm{m} \quad=$ modulus (batas maks bilangan acak)

$\mathrm{Xn}-1$ = bilangan acak sebelumnya

a $\quad$ factor penggali

$\mathrm{b} \quad=$ penambah (increment)

Kunci pembangkit adalah X0 yang merupakan nilai pertama kali yang muncul pada pengacakan yang didapat secara acak. LCM mempunyai periode tidak lebih besar dari $\mathrm{m}$, dan pada kebanyakan kasus periodenya kurang dari itu.

LCM mempunyai periode penuh (m - 1) jika memenuhi syarat berikut :

1 . $b$ relative prima terhadap $m$.

2. a -1 dapat dibagi dengan semua factor prima dari $\mathrm{m}$.

3. a -1 adalah kelipatan 4 jika $m$ adalah kelipatan 4.

4. $\mathrm{m}>\mathrm{mmmm}(\mathrm{a}, \mathrm{b}, \mathrm{x} 0)$

5. $a>0, b>0$

Meskipun LCM secara teoritis mampu menghasilkan bilangan acak yang lumayan, namun sangat sensitif terhadap pemilihan nilai-nilai a, b, dan m. pemilihan nilai-nilai yang tidak sesuai dapat mempengaruhi implementasi pada LCM.

\section{E. Android}

Android merupakan OS Mobile yang tumbuh di tengah OS lainnya yang berkembang saat ini. OS lainnya seperti Windows Phone, iPhone OS, Symbian, dan masih banyak lagi juga menawarkan kekayaan isi dan keoptimalan berjalan dengan memprioritaskan aplikasi inti yang dibangun sendiri tanpa melihat potensi yang cukup besar dari aplikasi pihak ketiga. Oleh karena itu, adanya keterbatasan dari aplikasi pihak ketiga untuk mendapatkan data asli ponsel, berkomunikasi antar proses serta keterbatasan distribusi aplikasi pihak ketiga untuk platform mereka.

Android menawarkan lingkungan yang berbeda untuk pengembangan. Setiap aplikasi memiliki tingkatan yang sama. Android tidak membedakan antara aplikasi inti dengan aplikasi pihak ketiga. API yang disediakan menawarkan akses ke hardware, maupun data-data ponsel sekalipun atau data sistem sendiri. Bahkan pengguna dapat menghapus aplikasi inti dan menggantikannya dengan aplikasi pihak ketiga. Android merupakan sistem operasi yang dikembangkan untuk perangkat mobile berbasis Linux. Pada awalnya sistem operasi ini dikembangkan oleh Android inc yang kemudian dibeli oleh Google pada tahun 2005. 
Jurnal Pseudocode, Volume VIII Nomor 1, Februari 2021, ISSN 2355-5920, e-ISSN 2655-1845 www.ejournal.unib.ac.id/index.php/pseudocode

\section{METODE PENELITIAN}

\section{A. Alur Kerja}

Berikut adalah alur kerja yang dilakukan pada penelitian ini :

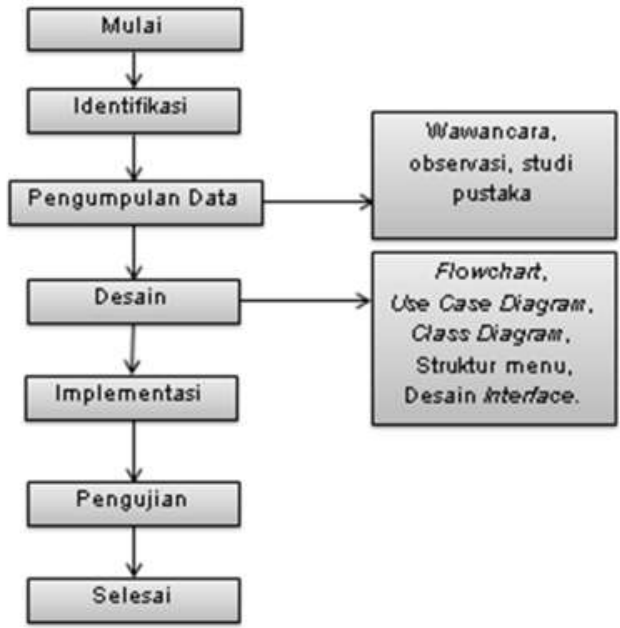

Gambar 1. Alur Kerja

Keterangan Alur Kerja :

1. Mulai, yaitu langkah awal penulis dalam melakukan perencanaan penelitian.

2. Identifikasi masalah, yaitu upaya penulis dalam mendefinisikan permasalahan mengenai aplikasi mobile game sebagai media alternatif edukasi kepada anak prasekolah.

3. Pengumpulan data, yaitu tahap pengumpulan data terbagi menjadi tiga bagian yaitu : tahap wawancara, studi pustaka, dan observasi objek.

4. Desain, pada tahap ini terdapat tiga bagian dalam perancangan aplikasi yaitu : flowchart, use case diagram, class diagram, struktur menu, dan desain interface.

5. Implementasi, yaitu proses penerapan metode kedalam aplikasi pemrograman.

6. Pengujian. Pengujian disini menggunakan pengujian black-box dimana tester berfokus pada fungsional aplikasi apakah sudah berjalan sesuai dengan yang diharapkan tanpa melihat coding. Kemudian menggunakan pengujian kuisioner, dimana sistem pengujian ini digunakan untuk mengetahui respon yang diberikan terhadap kepuasan aplikasi yang digunakan. Misalnya aplikasi game edukasi ini termasuk ke dalam kategori sangat baik, baik, cukup, tidak baik, atau sangat tidak baik.

B. Metode Pengembangan Sistem

Metode yang digunakan dalam melaksanakan penelitian adalah menggunakan metode pengembangan Multimedia menurut Luther Sutopo. Yang terdiri dari enam tahap, yaitu concept, design, material-collecting, assembly, testing, dan distribution.

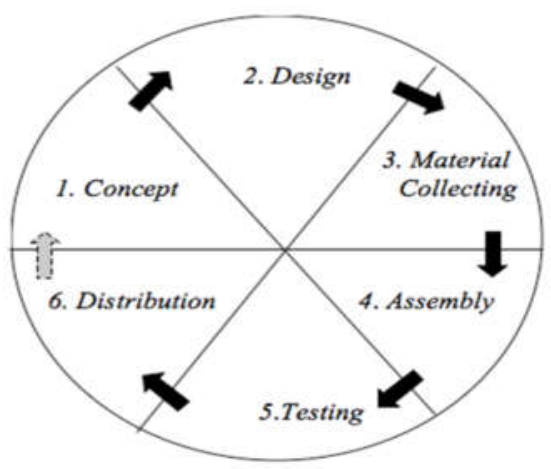

Gambar 2. Metode Pengembangan Sistem [15]

Adapun tahapannya sebagai berikut :

1. Konsep (Concept)

Pada tahap konsep, adalah tahap untuk menentukan tujuan dan siapa pengguna program (identifikasi audiens) dan juga materi harus dipersiapkan sebaik mungkin terutama soal-soal yang nantinya akan dimasukkan kedalam game edukasi ini, karna soal-soal itulah yang menjadi bahan utama yang harus ada dalam sebuah game edukasi untuk pembelajaran.

2. Perancangan (Design)

Konsep yang sudah matang akan memudahkan dalam menggambarkan apa yang harus dilakukan. Tujuan dari tahap perancangan (design) adalah membuat 
Jurnal Pseudocode, Volume VIII Nomor 1, Februari 2021, ISSN 2355-5920, e-ISSN 2655-1845 www.ejournal.unib.ac.id/index.php/pseudocode

spesifikasi secara terperinci mengenai arsitektur program, tampilan, dan kebutuhan material atau bahan dalam pengembangan aplikasi.

3. Pengumpulan data (Material Collecting)

Adapun tahap pengumpulan materi yang sesuai dengan kebutuhan yang dikerjakan. Bahan-bahan tersebut, antara lain gambar clip art, foto, animasi, audio, dan lain-lain.

4. Pembuatan (Assembly)

Tahap assembly adalah tahap pembuatan, aplikasi yang akan dibuat didasarkan pada tahap design, tahap dimana hasil design aplikasi diterjemahkan dalam bahasa yang dapat dimengerti oleh komputer. Dalam penelitian ini aplikasi android studio yang menggunakan Java.

\section{Pengujian (Testing)}

Setelah program aplikasi selesai dibuat (assembly) selanjutnya melakukan pengujian. Tahap pengujian dilakukan dengan menggunakan metode black-box dan kuisioner. Pengujian dilakukan untuk memastikan bahwa hasil pembuatan aplikasi sesuai rencana dan sesuai dengan rancangan dan dilihat apakah ada kesalahan atau tidak, dan aplikasi yang dibangun termasuk kedalam kategori sangat baik, baik, atau tidak baik.

6. Distribusi (Distribution)

Merupakan tahap akhir dalam pengembangan game. Pada tahap ini dilakukan proses penyebar luasan game yang telah diuji. Proses penyebarluasan dapat dilakukan dengan menggunakan system standalone yaitu dengan menggunakan Compact Disc atau secara online.

\section{Metode Pengumpulan Data}

Dalam pengumpulan data dan informasi untuk penulisan penelitian ini, penulis menggunakan teknik pengumpulan data sebagai berikut :

\section{Metode Wawancara}

Pengumpulan data yang dilakukan oleh peneliti untuk memperoleh informasi langsung dari sumbernya. Wawancara dilakukan kepada pengajar dan anak-anak didik.

2. Metode Observasi Objek

Metode ini dipakai penulis untuk mendapatkan data dan informasi dengan melakukan pengamatan secara langsung.

3. Metode Studi Pustaka

Pengumpulan data yang dilakukan oleh peneliti dengan mengumpulkan data yang berasal dari bahan pustaka seperti jurnal tentang Game Edukasi Berbasis Androd. Selain itu juga menggunakan data yang bersumber dari buku.

\section{Analisis Masalah}

Analisis yang dimaksud adalah bagaimana mengetahui masalah yang ada pada saat ini dan apa saja yang diperlukan untuk membuat suatu aplikasi yang dapat digunakan dan menjadi aplikasi yang bermanfaat serta edukatif (mendidik) bagi pengguna. Bagaimana membuat game edukasi pembelajaran huruf hijaiyah berbasis android yang dapat menarik minat belajar sehingga dapat diterapkan dan mudah dimengerti, dengan menggunakan Linear Congruent Method (LCM). 
Jurnal Pseudocode, Volume VIII Nomor 1, Februari 2021, ISSN 2355-5920, e-ISSN 2655-1845 www.ejournal.unib.ac.id/index.php/pseudocode

\section{E. Perancangan Sistem}

Perancangan Sistem yang dibangun menggunakan beberapa permodelan UML, yaitu :

\section{Flowchart}

Flowchart adalah bagan (chart) yang menunjukkan hasil (flow) didalam program atau prosedur sistem secara logika. Flowchart ini juga menggambarkan hubungan antara pengguna dengan perangkat lunak game edukasi berbasis android. Flowchart tersebut dapat kita lihat pada gambar di bawah ini

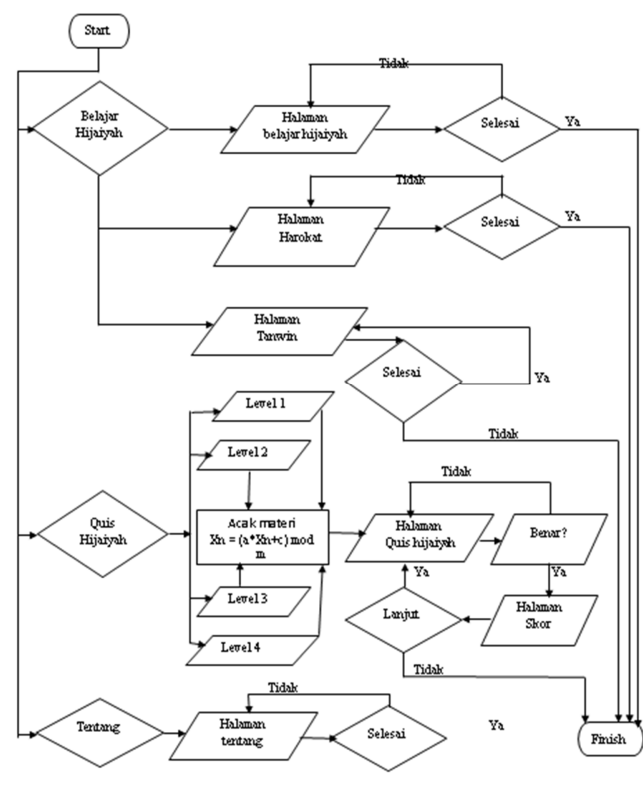

Gambar 3. Flowchart

\section{Use Case Diagram}

Sebuah use case menggambarkan interaksi antara actor dengan sistem dari fungsionalitas dari aplikasi game edukasi. Pada diagram use case untuk pemain seperti yang tampak pada gambar. Pemain dapat memainkan game.

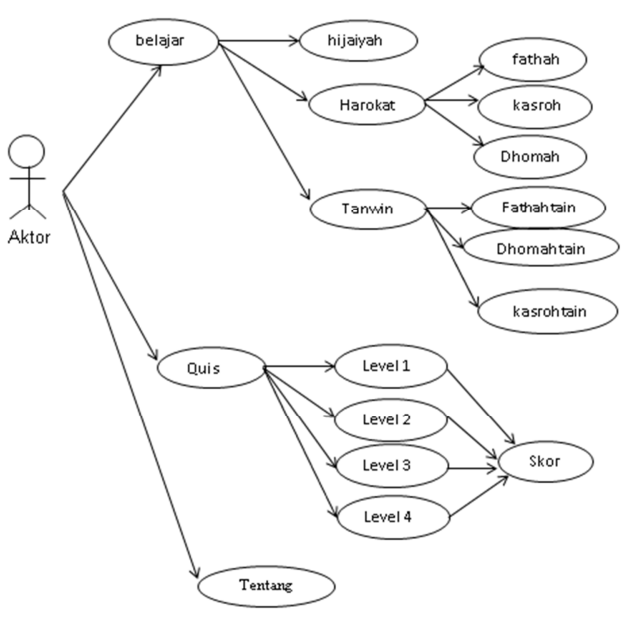

Gambar 4. Use Case diagram

\section{HASIL DAN PEMBAHASAN}

Pada bab ini penulis akan membahas aplikasi game edukasi pembelajaran huruf hijaiyah menggunakan Linear Congruent Method (LCM) berbasis android yang telah dibangun. Aplikasi dibangun menggunakan bahasa pemrograman java dengan software android studio.

\section{A. Tampilan Aplikasi}

Adapun tampilan aplikasi game edukasi yang dibangun adalah sebagai berikut:

1. Tampilan Menu Utama

Aplikasi akan menampilkan menu utama ketika pertama kali dijalankan. Tampilan menu awal berisi tiga menu utama, yaitu belajar, quis dan tentang. Menu belajar berfungsi untuk menampilkan halaman materi pembelajaran hijaiyah. Menu quis berfungsi untuk menampilkan halaman soal-soal pertanyaan. Menu tentang berfungsi untuk menampilkan halaman tentang.

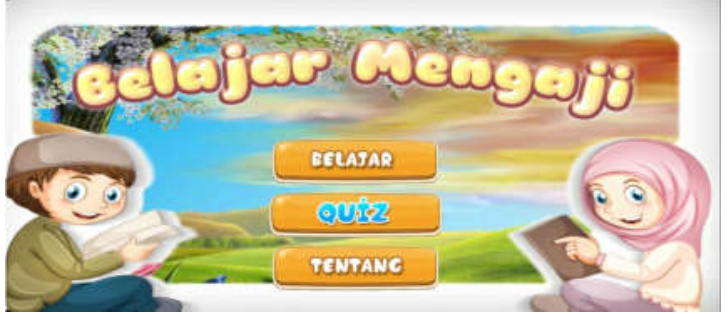

Gambar 5. Tampilan Menu Utama 
Jurnal Pseudocode, Volume VIII Nomor 1, Februari 2021, ISSN 2355-5920, e-ISSN 2655-1845

www.ejournal.unib.ac.id/index.php/pseudocode

\section{Tampilan Menu Belajar}

Halaman Belajar merupakan halaman yang digunakan untuk menampilkan pembelajaran dengan beberapa menu, antara lain menu hijaiyah, harokat dan tanwin.

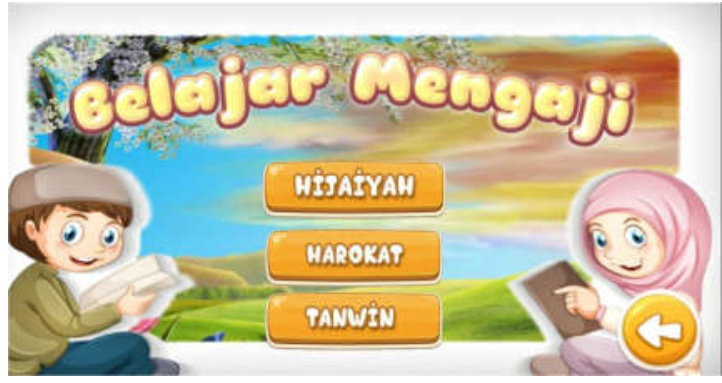

Gambar 6. Tampilan Menu Belajar

3. Tampilan Huruf Hijaiyah

Jika menu hijaiyah diklik, maka akan tampil halaman belajar huruf hijaiyah seperti terlihat pada Gambar 7 berikut.

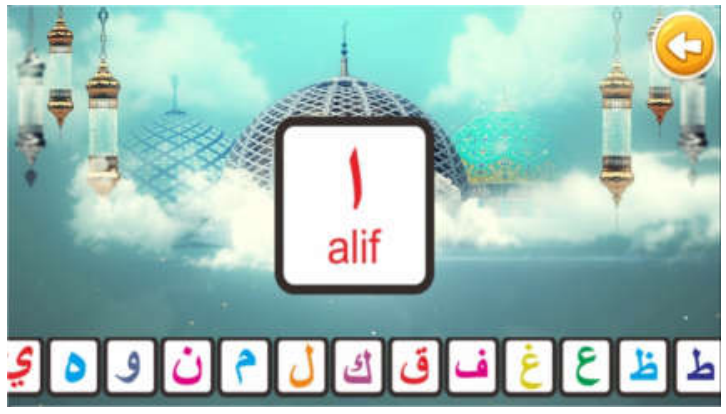

Gambar 7. Tampilan Huruf Hijaiyah

\section{Tampilan Harokat}

Halaman harokat akan tampil jika pengguna mengklik menu harokat yang ada dihalaman belajar. Halaman ini akan menampilkan menu harokat fathah, harokat dhomah dan harokat kasroh. Menu harokat fathah akan menampilkan materi harokat fathah, menu harokat kasroh akan menampilkan materi harokat kasroh dan menu harokat dhomah akan menampilkan materi harokat dhomah.

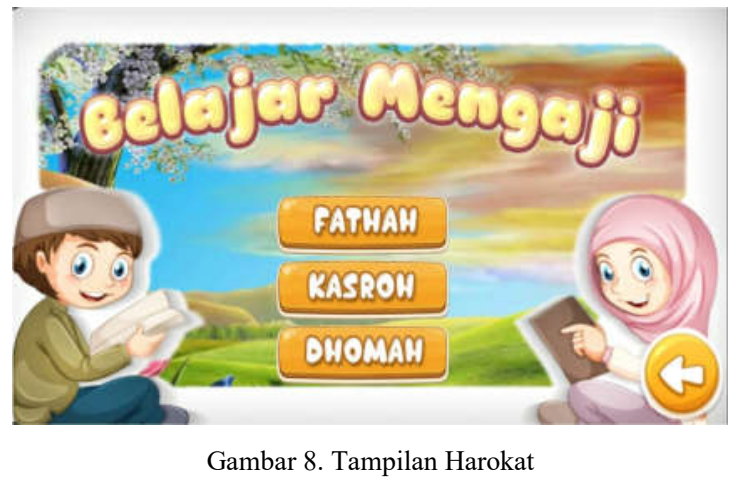

Pada setiap halaman terdapat tombol yang bisa diklik dan akan menampilkan popup huruf tersebut beserta suara pengucapannya. Tombol yang terdapat pada kanan atas merupakan tombol kembali.

5. Tampilan Menu Quis

Pada Tampilan Menu Quis terdapat pilihan level 1, level 2, level 3, dan level 4.

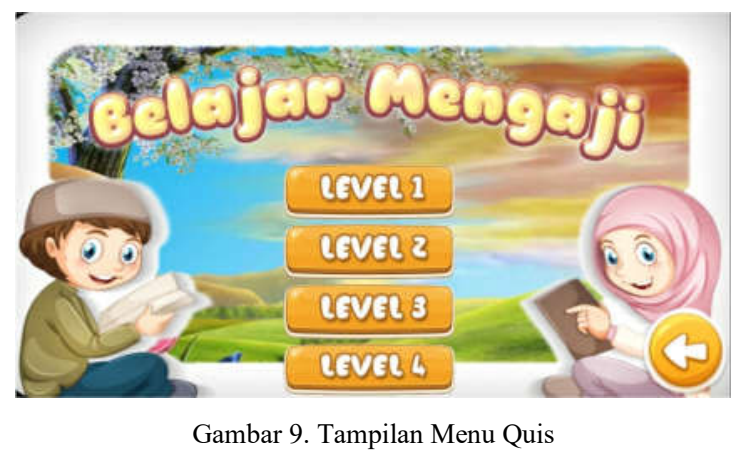

Halaman selanjutnya menampilkan soal dengan memberikan 3 pilihan jawaban. Soal yang tampil akan diacak menggunakan algoritme Linear Congruent Method.

6. Tampilan Menu Nilai

Setelah menjawab soal quis pada aplikasi, selanjutnya akan muncul tampilan menu nilai pada masing-masing level.

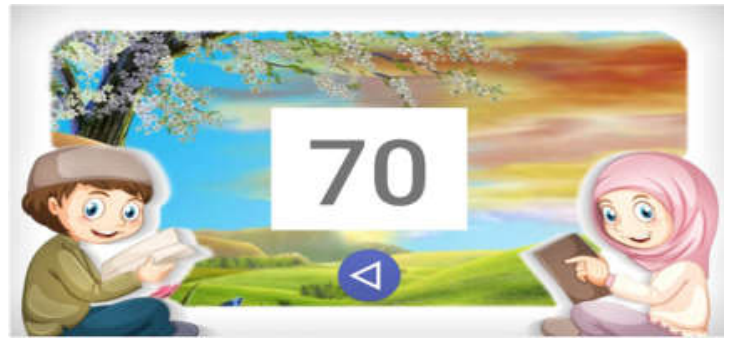

Gambar 10. Tampilan Menu Nilai 
Jurnal Pseudocode, Volume VIII Nomor 1, Februari 2021, ISSN 2355-5920, e-ISSN 2655-1845 www.ejournal.unib.ac.id/index.php/pseudocode

\section{B. Penerapan Algoritme Linear Congruent Method (LCM)}

Proses pengacakan soal pada halaman quis menggunakan algoritme Linear Congruent Method (LCM). LCM adalah algoritme yang sering diimplementasikan pada beberapa bahasa pemrograman dengan membangkitkan bilangan acak pada proses perhitungannya yang akan menghasilkan urutan soal yang baru. Proses perhitungannya adalah sebagai berikut :

Model matematis LCM dapat dihitung dengan menggunakan persamaan

$$
\mathrm{X} \_\mathrm{n}=\left(\left(\mathrm{a} * \mathrm{X} \_(\mathrm{n}-1)\right)+\mathrm{b}\right) \bmod \mathrm{m}
$$

Keterangan :

$$
\begin{array}{ll}
\text { X_(n+1) } & =\text { Soal berikutnya } \\
X_{-} n & =\text { Soal yang tampil } \\
\text { a } & =\text { nilai acak (bil prima antara } 1 \text { dan 28) } \\
\mathrm{b} & =\text { nilai acak (bil prima antara } 1 \text { dan 28) } \\
\mathrm{m} & =\text { jumlah soal (28) }
\end{array}
$$

$\mathrm{a}=5, \mathrm{X} 0=3, \mathrm{~b}=7, \mathrm{~m}=28$

Penyelesaian :

Tabel 1. Hasil Perhitungan

\begin{tabular}{|c|c|c|}
\hline Soal & Hitung & Hasil \\
\hline 1 & $(5 \times 3)+7) \bmod 28$ & 22 \\
\hline 2 & $(5 \times 22)+7) \bmod 28$ & 5 \\
\hline 3 & $(5 \times 5)+7) \bmod 28$ & 4 \\
\hline 4 & $(5 \times 4)+7) \bmod 28$ & 27 \\
\hline 5 & $(5 \times 27)+7) \bmod 28$ & 2 \\
\hline 6 & $(5 \times 2)+7) \bmod 28$ & 17 \\
\hline 7 & $(5 \times 17)+7) \bmod 28$ & 8 \\
\hline 8 & $(5 \times 8)+7) \bmod 28$ & 19 \\
\hline 9 & $(5 \times 19)+7) \bmod 28$ & 18 \\
\hline 10 & $(5 \times 18)+7) \bmod 28$ & 13 \\
\hline
\end{tabular}

\section{Pengujian}

Penulis menggunakan metode blackbox dan kuesioner.

\begin{tabular}{|c|c|c|c|}
\hline \multicolumn{2}{|l|}{ Pengujian } & \multirow{2}{*}{$\begin{array}{l}\text { Hasil yang } \\
\text { diharapkan }\end{array}$} & \multirow{2}{*}{$\begin{array}{l}\text { Hasil } \\
\text { Tes }\end{array}$} \\
\hline Halaman & $\begin{array}{l}\text { Butir } \\
\text { Uji }\end{array}$ & & \\
\hline \multirow{3}{*}{$\begin{array}{l}\text { Menu } \\
\text { Utama }\end{array}$} & $\begin{array}{l}\text { Tombol } \\
\text { Belajar }\end{array}$ & $\begin{array}{l}\text { Menampilkan halaman } \\
\text { Belajar }\end{array}$ & $\sqrt{ }$ \\
\hline & $\begin{array}{l}\text { Tombol } \\
\text { Quis }\end{array}$ & $\begin{array}{l}\text { Menampilkan halaman } \\
\text { Quis }\end{array}$ & $\sqrt{ }$ \\
\hline & $\begin{array}{l}\text { Tombol } \\
\text { Tentang }\end{array}$ & $\begin{array}{l}\text { Menampilkan halaman } \\
\text { Tentang }\end{array}$ & $\sqrt{ }$ \\
\hline \multirow{4}{*}{$\begin{array}{l}\text { Halaman } \\
\text { Belajar }\end{array}$} & $\begin{array}{l}\text { Tombol } \\
\text { Hijaiyah }\end{array}$ & $\begin{array}{l}\text { Menampilkan halaman } \\
\text { hijaiyah }\end{array}$ & $\sqrt{ }$ \\
\hline & $\begin{array}{l}\text { Tombol } \\
\text { Harokat }\end{array}$ & $\begin{array}{l}\text { Menampilkan halaman } \\
\text { Harokat }\end{array}$ & $\sqrt{ }$ \\
\hline & $\begin{array}{l}\text { Tombol } \\
\text { Tanwin }\end{array}$ & $\begin{array}{l}\text { Menampilkan halaman } \\
\text { Tanwin }\end{array}$ & $\sqrt{ }$ \\
\hline & $\begin{array}{l}\text { Tombol } \\
\text { Kembali }\end{array}$ & $\begin{array}{l}\text { Kembali kehalaman } \\
\text { Menu Utama }\end{array}$ & $\sqrt{ }$ \\
\hline \multirow{4}{*}{$\begin{array}{l}\text { Halaman } \\
\text { Hijaiyah }\end{array}$} & $\begin{array}{l}\text { Popup } \\
\text { Huruf }\end{array}$ & $\begin{array}{l}\text { Menampilkan popup } \\
\text { huruf hijaiyah yang } \\
\text { dipilih }\end{array}$ & $\sqrt{ }$ \\
\hline & $\begin{array}{l}\text { Tombol } \\
\text { Huruf }\end{array}$ & $\begin{array}{l}\text { Menampilkan tombol } \\
\text { huruf hijaiyah }\end{array}$ & $\sqrt{ }$ \\
\hline & Suara & 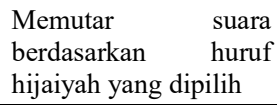 & $\sqrt{ }$ \\
\hline & $\begin{array}{l}\text { Tombol } \\
\text { Kembali }\end{array}$ & $\begin{array}{l}\begin{array}{l}\text { Kembali kehalaman } \\
\text { sebelumnya }\end{array} \\
\end{array}$ & $\sqrt{ }$ \\
\hline \multirow{4}{*}{$\begin{array}{l}\text { Halaman } \\
\text { Harokat }\end{array}$} & $\begin{array}{l}\text { Tombol } \\
\text { Harokat } \\
\text { fathah }\end{array}$ & $\begin{array}{l}\text { Menampilkan halaman } \\
\text { harokat fathah }\end{array}$ & $\sqrt{ }$ \\
\hline & $\begin{array}{l}\text { Tombol } \\
\text { Harokat } \\
\text { kasroh } \\
\end{array}$ & $\begin{array}{l}\text { Menampilkan halaman } \\
\text { harokat kasroh }\end{array}$ & $\sqrt{ }$ \\
\hline & $\begin{array}{l}\text { Tombol } \\
\text { Harokat } \\
\text { dhomah }\end{array}$ & $\begin{array}{l}\text { Menampilkan halaman } \\
\text { harokat dhomah }\end{array}$ & $\sqrt{ }$ \\
\hline & $\begin{array}{l}\text { Tombol } \\
\text { Kembali }\end{array}$ & $\begin{array}{l}\text { Kembali kehalaman } \\
\text { sebelumnya }\end{array}$ & $\sqrt{ }$ \\
\hline \multirow{4}{*}{$\begin{array}{l}\text { Halaman } \\
\text { Harokat } \\
\text { fathah }\end{array}$} & $\begin{array}{l}\text { Popup } \\
\text { Huruf }\end{array}$ & $\begin{array}{l}\text { Menampilkan popup } \\
\text { huruf harokat fathah } \\
\text { yang dipilih }\end{array}$ & $\sqrt{ }$ \\
\hline & $\begin{array}{l}\text { Tombol } \\
\text { Huruf }\end{array}$ & $\begin{array}{l}\text { Menampilkan tombol } \\
\text { huruf harokat fathah }\end{array}$ & $\sqrt{ }$ \\
\hline & Suara & $\begin{array}{ll}\text { Memutar } & \text { suara } \\
\text { berdasarkan } & \text { huruf } \\
\text { harokat fathah } & \text { yang } \\
\text { dipilih } & \end{array}$ & $\sqrt{ }$ \\
\hline & $\begin{array}{l}\text { Tombol } \\
\text { Kembali }\end{array}$ & $\begin{array}{l}\text { Kembali kehalaman } \\
\text { harokat }\end{array}$ & $\sqrt{ }$ \\
\hline $\begin{array}{l}\text { Halaman } \\
\text { Harokat } \\
\text { Kasroh }\end{array}$ & $\begin{array}{l}\text { Popup } \\
\text { Huruf }\end{array}$ & $\begin{array}{l}\text { Menampilkan popup } \\
\text { huruf harokat Kasroh } \\
\text { yang dipilih }\end{array}$ & $\sqrt{ }$ \\
\hline
\end{tabular}

\section{Pengujian Black Box}

Proses pengujian aplikasi dilakukan menggunakan sistem blackbox, dimana pengujian dilakukan dari segi user interface dan fungsinya.

Tabel 2. Hasil Pengujian Black Box 
Jurnal Pseudocode, Volume VIII Nomor 1, Februari 2021, ISSN 2355-5920, e-ISSN 2655-1845 www.ejournal.unib.ac.id/index.php/pseudocode

\begin{tabular}{|c|c|c|c|}
\hline & $\begin{array}{l}\text { Tombol } \\
\text { Huruf }\end{array}$ & $\begin{array}{l}\text { Menampilkan tombol } \\
\text { huruf harokat Kasroh }\end{array}$ & $\sqrt{ }$ \\
\hline & Suara & 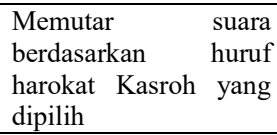 & $\sqrt{ }$ \\
\hline & $\begin{array}{l}\text { Tombol } \\
\text { Kembali }\end{array}$ & $\begin{array}{l}\text { Kembali kehalaman } \\
\text { harokat }\end{array}$ & $\sqrt{ }$ \\
\hline \multirow{4}{*}{$\begin{array}{l}\text { Halaman } \\
\text { Harokat } \\
\text { Dhomah }\end{array}$} & $\begin{array}{l}\text { Popup } \\
\text { Huruf }\end{array}$ & $\begin{array}{l}\text { Menampilkan popup } \\
\text { huruf harokat Dhomah } \\
\text { yang dipilih }\end{array}$ & $\sqrt{ }$ \\
\hline & $\begin{array}{l}\text { Tombol } \\
\text { Huruf }\end{array}$ & $\begin{array}{l}\text { Menampilkan tombol } \\
\text { huruf harokat Dhomah }\end{array}$ & $\sqrt{ }$ \\
\hline & Suara & $\begin{array}{lr}\text { Memutar } & \text { suara } \\
\text { berdasarkan } & \text { huruf } \\
\text { harokat Dhomah yang } \\
\text { dipilih }\end{array}$ & $\sqrt{ }$ \\
\hline & $\begin{array}{l}\text { Tombol } \\
\text { Kembali }\end{array}$ & $\begin{array}{l}\text { Kembali kehalaman } \\
\text { harokat }\end{array}$ & $\sqrt{ }$ \\
\hline \multirow{4}{*}{$\begin{array}{l}\text { Halaman } \\
\text { Tanwin }\end{array}$} & $\begin{array}{l}\text { Tombol } \\
\text { fathah } \\
\text { tain }\end{array}$ & $\begin{array}{l}\text { Menampilkan halaman } \\
\text { fathah tain }\end{array}$ & $\sqrt{ }$ \\
\hline & $\begin{array}{l}\text { Tombol } \\
\text { kasroh } \\
\text { tain }\end{array}$ & $\begin{array}{l}\text { Menampilkan halaman } \\
\text { kasroh tain }\end{array}$ & $\sqrt{ }$ \\
\hline & $\begin{array}{l}\text { Tombol } \\
\text { dhomah } \\
\text { tain }\end{array}$ & $\begin{array}{l}\text { Menampilkan halaman } \\
\text { dhomah tain }\end{array}$ & $\sqrt{ }$ \\
\hline & $\begin{array}{l}\text { Tombol } \\
\text { Kembali }\end{array}$ & $\begin{array}{l}\text { Kembali kehalaman } \\
\text { sebelumnya }\end{array}$ & $\sqrt{ }$ \\
\hline \multirow{4}{*}{$\begin{array}{l}\text { Halaman } \\
\text { Tanwin } \\
\text { Fathah }\end{array}$} & $\begin{array}{l}\text { Popup } \\
\text { Huruf }\end{array}$ & $\begin{array}{l}\text { Menampilkan popup } \\
\text { huruf fathah tain yang } \\
\text { dipilih }\end{array}$ & $\sqrt{ }$ \\
\hline & $\begin{array}{l}\text { Tombol } \\
\text { Huruf }\end{array}$ & $\begin{array}{l}\text { Menampilkan tombol } \\
\text { huruf fathah tain }\end{array}$ & $\sqrt{ }$ \\
\hline & Suara & 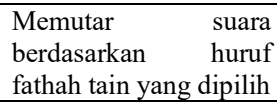 & $\sqrt{ }$ \\
\hline & $\begin{array}{l}\text { Tombol } \\
\text { Kembali }\end{array}$ & $\begin{array}{l}\text { Kembali kehalaman } \\
\text { tanwin }\end{array}$ & $\sqrt{ }$ \\
\hline \multirow{4}{*}{$\begin{array}{l}\text { Halaman } \\
\text { Tanwin } \\
\text { Kasroh }\end{array}$} & $\begin{array}{l}\text { Popup } \\
\text { Huruf }\end{array}$ & $\begin{array}{l}\text { Menampilkan popup } \\
\text { huruf kasroh tain yang } \\
\text { dipilih }\end{array}$ & $\sqrt{ }$ \\
\hline & $\begin{array}{l}\text { Tombol } \\
\text { Huruf }\end{array}$ & $\begin{array}{l}\text { Menampilkan tombol } \\
\text { huruf kasroh tain }\end{array}$ & $\sqrt{ }$ \\
\hline & Suara & $\begin{array}{lr}\text { Memutar } & \text { suara } \\
\text { berdasarkan huruf } \\
\text { kasroh tain } \\
\text { dipilih }\end{array}$ & $\sqrt{ }$ \\
\hline & $\begin{array}{l}\text { Tombol } \\
\text { Kembali }\end{array}$ & $\begin{array}{ll}\text { Kembali kehalaman } \\
\text { tanwin }\end{array}$ & $\sqrt{ }$ \\
\hline \multirow{4}{*}{$\begin{array}{l}\text { Halaman } \\
\text { Tanwin } \\
\text { Dhomah }\end{array}$} & $\begin{array}{l}\text { Popup } \\
\text { Huruf }\end{array}$ & $\begin{array}{l}\text { Menampilkan popup } \\
\text { huruf dhomah tain } \\
\text { yang dipilih }\end{array}$ & $\sqrt{ }$ \\
\hline & $\begin{array}{l}\text { Tombol } \\
\text { Huruf }\end{array}$ & $\begin{array}{l}\text { Menampilkan tombol } \\
\text { huruf dhomah tain }\end{array}$ & $\sqrt{ }$ \\
\hline & Suara & $\begin{array}{lr}\text { Memutar } & \text { suara } \\
\text { berdasarkan } & \text { huruf } \\
\begin{array}{l}\text { dhomah tain } \\
\text { dipilih }\end{array} & \\
\end{array}$ & $\sqrt{ }$ \\
\hline & $\begin{array}{l}\text { Tombol } \\
\text { Kembali }\end{array}$ & $\begin{array}{l}\text { Kembali kehalaman } \\
\text { tanwin }\end{array}$ & $\sqrt{ }$ \\
\hline \multirow{4}{*}{$\begin{array}{l}\text { Halaman } \\
\text { Quis }\end{array}$} & $\begin{array}{l}\text { Tombol } \\
\text { Level } 1 \\
\end{array}$ & $\begin{array}{l}\text { Menampilkan halaman } \\
\text { Level } 1\end{array}$ & $\sqrt{ }$ \\
\hline & $\begin{array}{l}\text { Tombol } \\
\text { Level } 2\end{array}$ & $\begin{array}{l}\text { Menampilkan halaman } \\
\text { Level } 2\end{array}$ & $\sqrt{ }$ \\
\hline & $\begin{array}{l}\text { Tombol } \\
\text { Level } 3 \\
\end{array}$ & $\begin{array}{l}\text { Menampilkan halaman } \\
\text { Level } 3\end{array}$ & $\sqrt{ }$ \\
\hline & Tombol & Menampilkan halaman & $\sqrt{ }$ \\
\hline
\end{tabular}

\begin{tabular}{|c|c|c|c|}
\hline & Level 4 & Level 4 & \\
\hline & $\begin{array}{l}\text { Tombol } \\
\text { Kembali }\end{array}$ & $\begin{array}{l}\text { Kembali kehalaman } \\
\text { sebelumnya }\end{array}$ & $\sqrt{ }$ \\
\hline \multirow{4}{*}{$\begin{array}{l}\text { Halaman } \\
\text { Level } \\
1,2,3 \text {, dan } \\
4\end{array}$} & $\begin{array}{l}\text { Popup } \\
\text { soal }\end{array}$ & $\begin{array}{l}\text { Menampilkan popup } \\
\text { soal }\end{array}$ & $\sqrt{ }$ \\
\hline & $\begin{array}{l}\text { Pilihan } \\
\text { jawaban }\end{array}$ & $\begin{array}{l}\text { Menampilkan Pilihan } \\
\text { jawaban }\end{array}$ & $\sqrt{ }$ \\
\hline & $\begin{array}{l}\text { Pertanya } \\
\text { an } \\
\text { selanjutn } \\
\text { ya }\end{array}$ & $\begin{array}{l}\text { Menampilkan } \\
\text { Pertanyaan selanjutnya }\end{array}$ & $\sqrt{ }$ \\
\hline & $\begin{array}{l}\text { Tombol } \\
\text { Kembali }\end{array}$ & $\begin{array}{l}\text { Kembali kehalaman } \\
\text { sebelumnya }\end{array}$ & $\sqrt{ }$ \\
\hline \multirow{2}{*}{$\begin{array}{l}\text { Halaman } \\
\text { hasil }\end{array}$} & $\begin{array}{l}\text { Text } \\
\text { nilai }\end{array}$ & Menampilkan nilai & $\sqrt{ }$ \\
\hline & $\begin{array}{l}\text { Tombol } \\
\text { Kembali }\end{array}$ & $\begin{array}{l}\text { Kembali kehalaman } \\
\text { sebelumnya }\end{array}$ & $\sqrt{ }$ \\
\hline
\end{tabular}

\section{Pengujian Kuesioner}

Kuesioner diberikan kepada 10 responden, hasil pengolahan dari kuesioner dapat dilihat pada Gambar 11 berikut ini.

\begin{tabular}{|c|l|c|c|c|c|c|c|c|}
\hline No & Pertanyaan & $\mathbf{S}$ & $\mathbf{S}$ & $\mathbf{N}$ & $\begin{array}{r}\mathbf{T} \\
\mathbf{S}\end{array}$ & $\begin{array}{l}\mathbf{S} \\
\mathbf{T} \\
\mathbf{S}\end{array}$ & $\begin{array}{c}\text { Total } \\
\text { Nilai }\end{array}$ & $\begin{array}{c}\text { Persen } \\
\text { tase \% }\end{array}$ \\
\hline 1. & $\begin{array}{l}\text { Tampilan } \\
\text { game menarik }\end{array}$ & 4 & 4 & 1 & 0 & 0 & 39 & 78,00 \\
\hline 2. & $\begin{array}{l}\text { Game ini } \\
\text { membantu } \\
\text { dalam proses } \\
\text { pembelajaran } \\
\text { hijaiyah }\end{array}$ & 5 & 5 & 0 & 0 & 0 & 45 & 90,00 \\
\hline 3. & $\begin{array}{l}\text { Bahasa dalam } \\
\text { game sulit } \\
\text { dimengerti }\end{array}$ & 0 & 0 & 2 & 4 & 4 & 18 & 36,00 \\
\hline 4. & $\begin{array}{l}\text { Aplikasi ini } \\
\text { dapat menarik } \\
\text { minat anak } \\
\text { untuk belajar }\end{array}$ & 7 & 2 & 1 & 0 & 0 & 45 & 90,00 \\
\hline 5. & $\begin{array}{l}\text { Game ini asik } \\
\text { dimainkan }\end{array}$ & 3 & 5 & 3 & 0 & 0 & 44 & 88,00 \\
\hline \multicolumn{7}{|l|}{ Nilai rata-rata persentase : } & 76,40 \\
\hline
\end{tabular}

Berdasarkan hasil pengujian game edukasi pembelajaran huruf hijaiyah menggunakan Linear Congruent Method (LCM) berbasis android dengan menggunakan kuesioner aplikasi yang dibangun masuk ke kategori "Baik" dengan hasil rata-rata $76,40 \%$.

\section{KESIMPULAN DAN SARAN}

Berdasarkan hasil pembahasan dan pengujian pada penelitian ini dapat disimpulkan bahwa Linear Congruent Method dapat diimplementasikan pada aplikasi game edukasi 
Jurnal Pseudocode, Volume VIII Nomor 1, Februari 2021, ISSN 2355-5920, e-ISSN 2655-1845 www.ejournal.unib.ac.id/index.php/pseudocode

pembelajaran huruf hijaiyah. Setelah dilakukan pengujian aplikasi menggunakan blackbox, dapat diketahui bahwa semua tombol pada aplikasi dapat digunakan sesuai dengan yang diharapkan. Sedangkan pada pengujian kuesioner dapat disimpulkan bahwa aplikasi yang dibangun masuk ke kategori "Baik" dengan hasil rata-rata 76,40\%. Ke depannya diharapkan game edukasi ini terus dikembangkan untuk penyesuaian kebutuhan pendidikan, mengingat semakin berkembangnya teknologi smartphone.

\section{REFERENSI}

[1] K. Adha, Mesran, and Murdani, "Penerapan Linear Congruent Method Pada Game Edukasi Tebak Huruf Hiragana Dan Katakana Berbasis Android Penerapan Linear Congruent Method Pada Game Edukasi Tebak Huruf Hiragana Dan Katakana Berbasis Android," $J$. Times, vol. VI, no. 1, pp. 6-11, 2017.

[2] Bursan and Fitriyah, "Perancangan Permainan ( Game ) Edukasi Belajar Membaca Pada Anak Prasekolah Berbasis Smartphone and," J. TEKNOIF, vol. 3, no. 1, pp. $62-70,2015$

[3] M. I. Hanafri, A. Budiman, and N. A. Akbar, "Game Edukasi Tebak Gambar Bahasa Jawa Menggunakan Adobe Flash CS6 Berbasis Android," J. Sisfotek Glob. vol. 5, no. 2, pp. 50-53, 2015.

[4] M. Rinaldi and R. D. Sianturi, "Perancangan Aplikasi Game Edukasi Reaksi Unsur Kimia Menggunakan Metode Linear Congruent Method ( LCM )," J. Ris. Komput., vol. 5, no. 2, pp. 247-253, 2018.

[5] Dora et.al, "Perancangan Aplikasi Game Edukasi Pembelajaran Anak Usia Dini Menggunakan Linear Congruent Method ( Lcm ) Berbasis Android," J. Inform. Glob., vol. 6, no. 1, pp. 7-14, 2015.

[6] F. T. Romadhona and E. Yundra, "Pengembangan Edugame sebagai Media Pembelajaran Berbasis Role
Play Game (RPG) pada Mata Pelajaran Simulasi Digital Kelas X TAV di SMKN 3 Surabaya," Pendidik. Tek. Elektro, vol. 07, no. 2, pp. 101-107, 2018.

[7] A. V. Vitianingsih, "Game Edukasi Sebagai Media Pembelajaran PAUD," J. Inf., vol. 1, no. 1, pp. 1-8, 2016.

[8] D. R. Purnamasari, "Implementasi Linear Congruent Method ( $\mathrm{Lcm}$ ) Pada Game Hangaroo Berbasis Android," J. Ris. Komput., vol. 3, no. Lcm, pp. 1-6, 2016.

[9] I. T. Santi and Sukadi, "Pembuatan Game Pembelajaran Pengenalan Huruf Hijaiyah Di Taman Kanak-Kanak (TK) Az-Zalfa Sidoharjo Pacitan," J. Speed-Sentra Penelit. Eng. dan Edukasi, vol. 6, no. 1, p. 7, 2015.

[10] E. Ekojono, R. Cahyaningrum, and K. S. Batubulan, "Implementasi Metode Fisher-Yates Shuffle Dan Fuzzy Tsukamoto Pada Game 2D Gopoh Berbasis Android," J. Inform. Polinema, vol. 4, no. 3, p. 174, 2018, doi: 10.33795/jip.v4i3.203.

[11] F. A. Asyraq, D. S. Hormansyah, and M. Astiningrum, "Implementasi Fsm (Finite State Machine) Pada Game Surabaya Membara," J. Inform. Polinema, vol. 6, no. 2, pp. 11-17, 2020, doi: 10.33795/jip.v6i2.278.

[12] W. Ramansyah, "Pengembangan Game Edukasi 'Aksara Jawa' Berbasis Unity Untuk Siswa Kelas 3 Sdn Mulyoarjo 3 Lawang," Edutic - Sci. J. Informatics Educ., vol. 2, no. 2, pp. 31-42, 2016, doi: 10.21107/edutic.v2i2.1577.

[13] D. Hurd and E. Jenuings, "Standardized Educational Game Ratings : 'Suggested Criteria," Karya tulis Ilm., 2009.

[14] A. B. UTOMO, "Aplikasi Tebak Gambar Pahlawan dan Candi Indonesia menggunakan Metode Linear Congruent Method (LCM)," UN PGRI KEDIRI, no. Lcm, pp. 1-10, 2016.

[15] M. Budihariawan, I. K. Sudarma, and I. N. Jampel, "Pengembangan Multimedia Interaktif Pada Mata Pelajaran IPA Untuk Kelas VII Di SMP Negeri 2 Kubutambahan," Edutech, vol. 2, no. 1,pp. 1-6, 2014. 